\title{
A novel homeobox gene, dharma, can induce the organizer in a non-cell-autonomous manner
}

\author{
Yojiro Yamanaka, ${ }^{1}$ Toshiro Mizuno, ${ }^{2}$ Yoshiki Sasai, ${ }^{3}$ Masashi Kishi, ${ }^{3}$ Hiroyuki Takeda, ${ }^{2}$ \\ Cheol-Hee Kim, ${ }^{1}$ Masahiko Hibi, ${ }^{1}$ and Toshio Hirano ${ }^{1,4}$ \\ ${ }^{1}$ Division of Molecular Oncology, Biomedical Research Center, Osaka University M edical School; Osaka 565-0871, Japan; \\ ${ }^{2}$ Department of M olecular Biology, School of Science, N agoya University, N agoya 464-8602, Japan; ${ }^{3}$ Department \\ of Medical Embryology and N eurobiology, Institute for Frontier M edical Sciences, Kyoto University, Kyoto 606-8315, Japan
}

The formation of Spemann organizer is one of the most important steps in dorsoventral axis determination in vertebrate development. However, whether the organizer forms autonomously or is induced non-cell-autonomously is controversial. In this report we have isolated a novel zebrafish homeobox gene, dharma, capable of inducing the organizer ectopically. The expression of dharma was first detected in several blastomeres at one side of the margin soon after the mid-blastula transition and continued in the dorsal side of the yolk syncytial layer (YSL) under the embryonic shield, the zebrafish organizer, until the onset of gastrulation. Furthermore, dharma expressed in the YSL induced the organizer in a non-cell-autonomous manner. These results provided the first identification of a zygotic gene to be implicated in the formation of an organizer-inducing center.

[Key Words: Organizer; N ieuwkoop center; dharma; zebrafish; yolk syncytial layer]

Received March 30, 1998; revised version accepted June 3, 1998.

In the field of developmental biology, one of the major issues to resolve is how the dorsoventral (DV) axis is established in early vertebrate embryogenesis. Transplantation studies of amphibian embryos have revealed that three inductive signals play essential roles in establishing the DV axis (N ieuwkoop 1969; Slack 1994; Heasman 1997). In this "three-signal" model, two mesoderminducing signals are released from the vegetal blastomeres at the blastula stage. The dorsal-vegetal region, referred to as the $\mathrm{N}$ ieuwkoop center, induces dorsal mesoderm in the dorsal marginal zone to become the Spemann organizer, and the ventral-vegetal cells induce ventral mesoderm in the ventral marginal zone. Subsequently, the organizer generates a third inductive signal that promotes dorsalization of the more lateral mesoderm to extend the DV axis pattern in the mesoderm. Recent studies have been focused on identifying the molecules responsible for these inductive signals. Many of the identified molecules have been shown to be involved in the signal generated from the organizer (Lemaire and Kodjabachian 1996; M oon et al. 1997a; Sasai and De Robertis 1997). However, little is known about the molecules involved in the inductive signals for the formation of the Spemann organizer.
In disagreement with the three-signal model, other lines of evidence have raised controversial issues concerning the formation of the Spemann organizer by inductive signals. In Xenopus embryos, the initial dorsal axis determination is believed to be governed by the dorsal determinants (DDs), which are initially local ized at the vegetal pole (Sakai 1996; Darras et al. 1997; Heasman 1997; Laurent et al. 1997). During the cortical rotation, the DDs move to the dorsal marginal zone where they are incorporated into the prospective organizer tissue. Furthermore, blastomeres in the dorsal marginal zone are fated to become the prospective organizer at the 32cell stage (Takasaki 1987; Gal lagher et al. 1991; Bauer et al. 1994; Lemaire and Gurdon 1994) and dorsalizing signals are released not only from dorsal vegetal, but from equatorial and animal cells (Kageura 1990). These results suggest that the organizer is al ready determined autonomously by the DDs in Xenopus embryos before the blastula stage, in which the $\mathrm{N}$ ieuwkoop center is believed to induce the organizer. In short, it is still uncertain whether a cell-autonomous or non-cell-autonomous mechanism acts physiologically in the formation of the organizer in Xenopus.

In zebrafish, another model for studying vertebrate development, the blastoderm perches on the large yolk mass during cleavage and the blastula stage (Driever 1995; Westerfield 1995). The yolk does not undergo cleavage as in Xenopus embryos; instead, around the 
mid-blastula stage, the marginal cells in a deep layer of the blastoderm collapse, releasing their nuclei into the immediately adjoining cytoplasm of the yolk cell, thus forming the yolk syncytial layer (YSL). Although no apparent DV axis is observed at the mid-blastula stage, yolk transplantation experiments have revealed that the YSL of this stage possesses the ability to induce mesoderm and the organizer in the overlying blastoderm (M izuno et al. 1996).

Here we report the isolation of a novel zebrafish homeobox gene, dharma, using an expression cloning strategy. We found that dharma was expressed on the dorsal side of the YSL from the mid-blastula to the early gastrula stage, which is where and when the organizer-inducing activity is thought to exist. Furthermore, we found that dharma could confer this activity to the YSL. Our finding provides evidence for the non-cell-autonomous induction of the organizer in zebrafish.

\section{Results}

Expression cloning for the gene affecting DV axis formation

To isolate genes affecting the body axis formation, we used an expression cloning strategy in zebrafish similar to that used in Xenopus (Smith and Harland 1991; Smith and Harland 1992; Lemaire et al. 1995). In zebrafish, treatment of early-stage embryos with $\mathrm{LiCl}$ can induce hyperdorsalized phenotypes as in Xenopus embryos (Stachel et al. 1993). We constructed a plasmid cDN A library from LiCl-treated shiel d-stage embryos. We divided the library into subsets, each containing $\sim 200$ clones, and synthesized mRNAs from the plasmids in each set. We injected these mRNAs into embryos (30 embryos for one subset) from the one- to eight-cell stage. At $24 \mathrm{hr}$ after fertilization, we evaluated the effects of the mRNA injection on the axial formation by microscopic observation. For one subset, injected embryos displayed hyperdorsal ized phenotypes (Fig. IA,D). U sing si b selection, we isolated a clone that had a strong dorsal izing activity.

\section{Novel homeobox-containing gene dharma}

The isolated clone contained an 802-bp cDNA fragment that encoded a novel protein consisting of 192 amino acids and containing a homeodomain (Fig. 2A). We named this novel gene dharma, because embryos injected with it form eyes and a head but no trunk or tail (Fig. 1A,D), resembling a Japanese dharma doll (named for the famous Buddhist priest). The Dharma homeodomain was most closely related to those of Goosecoid (Gsc) and Drosophila brain-specific homeoprotein-9 (BSH9). The Dharma homeodomain contains 33 amino acids identical to both GsC and $\mathrm{BSH} 9$ homeodomains, which consist of 60 amino acids (Fig. 2B). Outside the homeobox, no significant similarity between Dharma and other proteins was found.

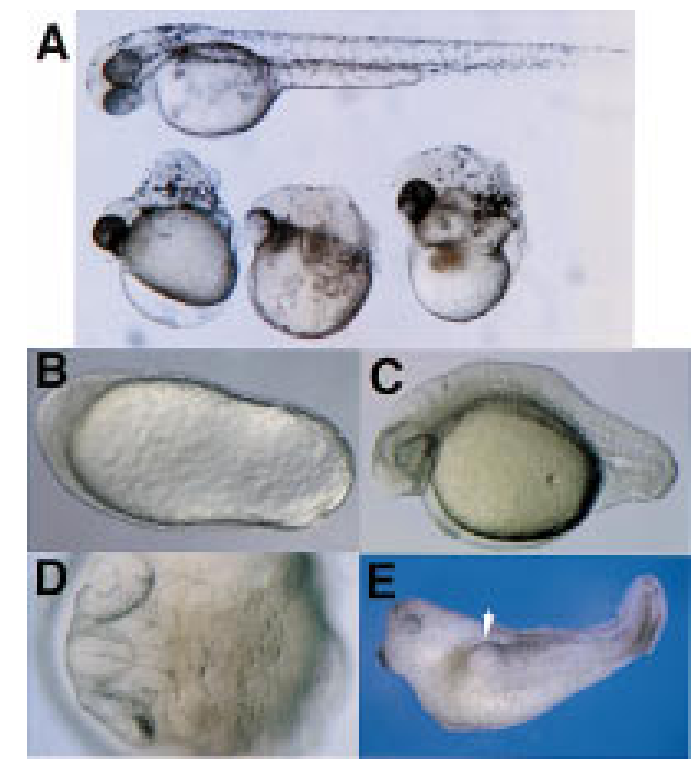

Figure 1. Phenotypes of dharma mRNA-injected embryos. (A) dharma mRN A (5 pg)-injected embryos at 48 pfh. (Top) N ormal embryo at 48 pfh. (Bottom) dharma mRNA-injected embryos with the Snh-like phenotype. (B-D) dharma RN A (12.5 pg)-injected embryos. (B) An embryo with football shape at $12 \mathrm{pfh}$. (C) An embryo tail malformation at 24 pfh. (D) An embryo Snh-like phenotype at 24 pfh (dorsal view). (E)The double-axis phenotype in the Xenopus embryo induced by dharma expression. Onehundred picograms of dharma mRNA was injected into the ventral-vegetal cell with $40 \mathrm{pg}$ of $\beta$-galactosidase mRNA. (White arrow head) Second axis. Out of 24 injected embryos, 9 embryos were normal, 11 contained double axes, 2 were dorsalized, and 2 had spina bifida. Of the 11 double-axis embryos, 9 exhibited X-gal staining only in the endoderm, and 2 exhibited $X$-gal staining in both the endoderm and the second axis. Control embryos injected with 100 pg of $\beta$-gal RNA were normal (data not shown).

Dorsalized phenotypes of the embryos injected with dharma mRNA

When 5 pg of dharma mRNA was injected into one-cellstage embryos, $83 \%$ of them displayed football shapes at the tail-bud stage (Table 1; Fig. 1B). At 24 postfertilization hours (pfh), 33\% of the embryos lacked an apparent axis (data not shown), 11\% displayed Snailhouse (Snh)like phenotypes (M ullins et al. 1995) in which the anterior structure formed normally but the trunk and tail structures did not el ongate (Fig. 1A,D), and 9\% had only tail malformations (Fig. 1C). These phenotypes indicate hyperdorsalization of the zebrafish, as has been reported for certain developmental mutants (Mullins et al . 1995; Hammerschmidt et al. 1996). When larger amounts of RNA were injected, the embryos displayed more severe phenotypes (Table 1).

To analyze the molecular events induced by the overexpression of dharma in zebrafish, we performed wholemount in situ hybridization. The injection of $12.5 \mathrm{pg}$ of dharma mRNA resulted in increased gsc expression, which spread into the margin at the shield stage (Fig. 3A, 
A

$\begin{array}{rllllr}1 & \text { MATQKFSNFS } & \text { IDYILGDTSR } & \text { QTAESPGVDH } & \text { PASSQDFQGH } & 40 \\ 41 & \text { LRKLDLLYQE } & \text { GCRGHCDRAA } & \text { LMVNFPCPSW } & \text { PGMYCCCVPV } & 80 \\ 81 & \text { SYYQSTYYAG } & \text { QPWPYAVAGC } & \text { ETAENHYHTI } & \text { AQRPRGQIRT } & 120 \\ 121 & \text { VFTDNOTEOL } & \text { ERLFAVTDYP } & \text { TVETRAELAO } & \text { NTGLSEETVR } & 160 \\ 161 & \text { VWFKMRRARR } & \text { KROTTCADKH } & \text { ANRALEDHQE } & \text { SD } & 192\end{array}$

B

BSH9 QRRSRTTFSNDQIDALERIFARTQYPDVYTREELAAOSTGLTEARVQVWF SNRRARLRKQL ||$:|::=|:|||:|||:|||||||||:||||:|||:|||||::|$

dharma RGQIRTVFTDNOTEQLERL FAVTDYPTVETRAELAQNTGLSEETVRVWFKNRRARRKROT

$\|:|||:||||\|||||||:||:::||||:|||||||::||$

Figure 2. dharma encodes a novel homeoprotein. (A) Amino acid sequence of Dharma. The homeodomain is underlined. (B) Comparison of the hogSC KRRHRTIFTDEQLEALENLFQETKYPDVGTREQLARKYHLREEKVEVWFKNRRAKWRRQK meodomains of Dharma, Gsc, and BSH9.

right). In controls gsc expression was restricted to the shield region (Fig. 3A, left) (Stachel et al. 1993; SchulteMerker et al. 1994). At the $80 \%$ epiboly stage, gsc expression was observed normally in the anterior hypoblast (Fig. 3B, left), but in dharma mRNA-injected embryos, gsc expression expanded into the marginal zone (Fig. 3B, right). Expression of ntl (no tail), a pan-mesodermal marker (Schulte-Merker et al. 1992), was detected in the margin at the shield stage, and was not affected by dharma mRNA injection (Fig. 3C). At the 90\% epiboly stage, ntl-expressing cells normally moved within the hypoblast into the dorsal midline to form the axial mesoderm. In contrast, in dharma mRN A-injected embryos, $\mathrm{ntl}$ expression expanded broadly into the vegetal side (Fig. 3D). We observed that some injected embryos had two or three anterior-posterior stripes of ntl expression at the tail-bud stage (Fig. 3E). These results indicate that the high expression of dharma induced ectopic organizers, resulting in the subsequent formation of expanded or multiple regions of axial mesoderm.

The activity of dharma in secondary axis formation in Xenopus embryo

N ext, we examined the axis-inducing activity of dharma using Xenopus embryos. The injection of dharma mRN A into one ventral-vegetal blastomere of Xenopus embryos at the ei ght-cell stage could induce a secondary axis in these embryos (Fig. 1E; 16/34 injected embryos). Histological analysis showed that these secondary axes $(n=16)$ contained a neural tube $(100 \%)$, somites $(100 \%)$, a gut $(50 \%)$, and otic vesicles $(43 \%)$, but no notochord or eyes (data not shown). Thus, zebrafish dharma could partially induce organizer activities in Xenopus and cause phenotypes similar to those caused by overexpression of gsc (Cho et al. 1991) or an activated Xlim-1 (Taira et al. 1992).

Temporal and spatial expression pattern of dharma

Analysis of the temporal expression of dharma in ze brafish by $\mathrm{N}$ orthern blotting revealed that it could be detected from a very early stage, the sphere stage, and that its expression could no longer be detected after the shield stage (Fig. 4A). In contrast, gsc expression was not detected until the shield stage and declined later, but it could be detected until the tail-bud stage. Expression of both genes was enhanced strongly at the shiel d stage by $\mathrm{LiCl}$ treatment. This result indicates that gsc expression is activated by dharma downstream of the $\mathrm{LiCl}$-dependent pathway.

The localization of dharma transcripts in developing embryos was examined by whole-mount in situ hybridization and sagittal sections of the stained embryos. dharma expression was detected in several blastomere cells on one side of the margin of embryos beginning at the high stage (Fig. 4B,G). Then, at the sphere stage, dharma expression was detected in the several marginal cells and a part of the YSL (Fig. 4C,H). After the sphere stage, its transcript was only detected in the one side of YSL at the dome stage (Fig. 4D,I) and at the $50 \%$ epiboly (Fig. 4E,J). At the shield stage, dharma expression continued to be detected in the YSL under the shield region (Fig. 4F,K) in contrast to gsc expression (Fig. 4L), which was detected in the hypoblasts, indicating that dharma is expressed in the dorsal side of YSL. In LiCl-treated embryos, dharma expression was enhanced and expanded within the internal-YSL (Fig. 4, cf. N and M).

Table 1. Dose effects of dharma RNA injection

\begin{tabular}{|c|c|c|c|c|c|c|c|c|c|c|c|c|}
\hline & \multirow{2}{*}{$\begin{array}{l}\text { Total } \\
\text { no. of } \\
\text { embryos }\end{array}$} & \multirow{2}{*}{$\begin{array}{l}\text { No. of } \\
\text { experi- } \\
\text { ments }\end{array}$} & \multicolumn{4}{|c|}{$12 \mathrm{pfh}^{\mathrm{a}}$} & \multicolumn{6}{|c|}{$24 \mathrm{pfh}^{\mathrm{b}}$} \\
\hline & & & $\mathrm{N}$ & FS & dead & others & $\mathrm{N}$ & TA & $\begin{array}{l}\text { Snh- } \\
\text { like }\end{array}$ & NOA & dead & others \\
\hline $\begin{array}{l}\text { Control } \\
\text { dharma } \\
\text { mRNA (pg) }\end{array}$ & 128 & 3 & $97(\%)$ & - & 1 & 2 & 9 & - & - & - & 1 & 2 \\
\hline 5 & 146 & 4 & 15 & 83 & 2 & - & 20 & 9 & 11 & 33 & 25 & - \\
\hline 12.5 & 134 & 4 & 1 & 98 & 1 & - & 3 & - & 7 & 54 & 35 & - \\
\hline 25 & 121 & 4 & 1 & 98 & 1 & - & 1 & - & 1 & 51 & 45 & - \\
\hline
\end{tabular}

a(N) N ormal; (FS) football shape.

b(N) N ormal; (TA) tail abnormality; (NOA) no obvious axis. 

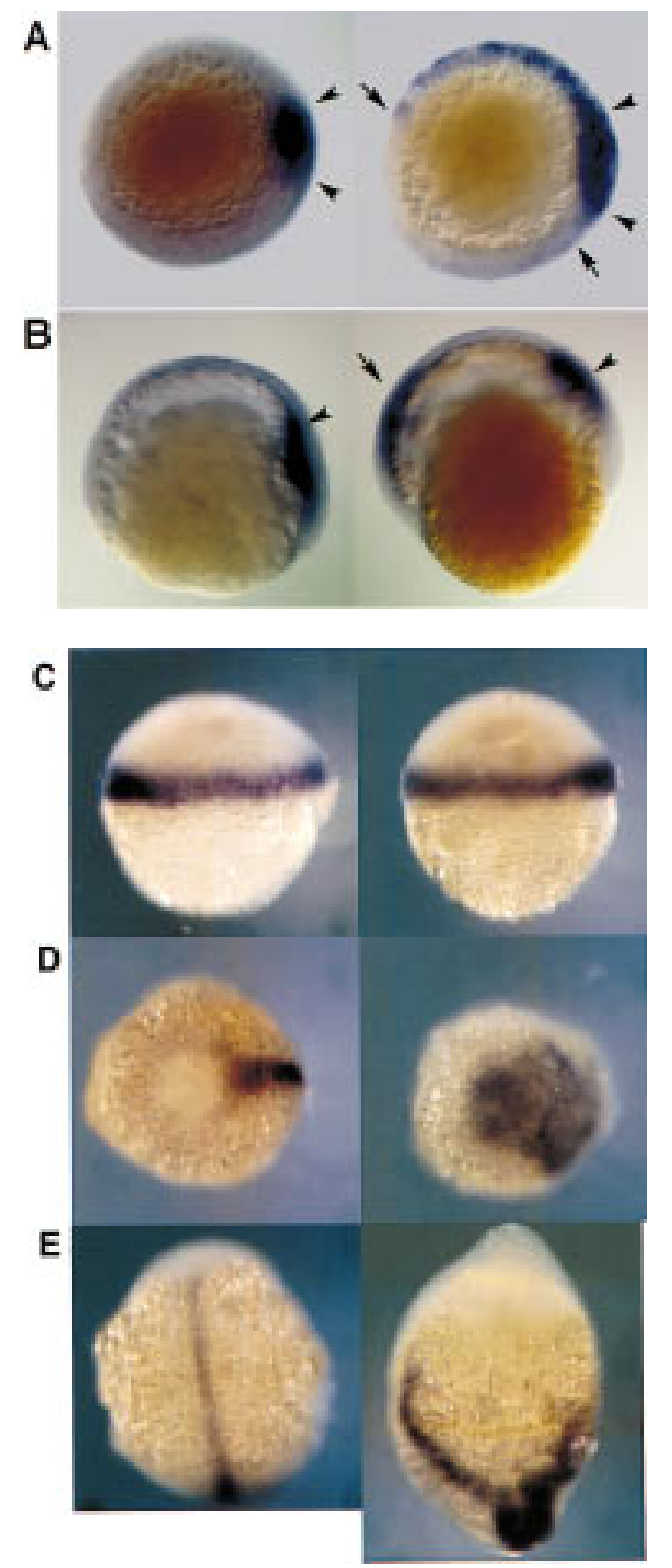

Figure 3. Overexpression of dharma mRNA induced the expansion of gsc expression but did not affect mesoderm formation. For each set of pictures, the embryo at left is the control and the one at right was injected with dharma mRN $A$. Right is dorsal (except $E)$. $(A, B)$ gsc expression at the shield stage $(A$, animal pole view), and at the $80 \%$ epiboly stage (B, lateral view). (Arrowheads) Region of endogenous gsc expression; (arrows) expanded gsc expression. (C-E) ntl expression at the shield stage (C, lateral view), at the $90 \%$ epiboly stage (D, vegetal pole view), and at the tailbud stage (E, dorsal view).

Dharma expressed in YSL induces the organizer in a non-cell-autonomous manner

The localization of dharma expression was distinct from that of gsc (Fig. 4K,L), raising the possibility that dharma induces the organizer in a non-cell-autonomous manner. To examine this possibility, we performed two experi- ments: yolk cell transplantation (Mizuno et al. 1996) and dharma overexpression in the YSL. For transplantation, a yolk cell was prepared from a dharma mRNA-injected embryo at the mid-blastula stage and transplanted onto the animal pole of a sibling (uninjected) embryo. Transpl anted embryos were then grown to the shi el d stage and subjected to whole-mount in situ hybridization. Ectopic gsc expression induced by the transplanted yolk cell was observed in control yolk-transplanted embryos (Fig. 5A, 10/10 embryos), as described previously (Mizuno et al. 1996). When a yolk cell from a dharma mRN A-injected embryo was transplanted, we observed an expansion of this ectopic gsc expression into the host blastomeres (Fig. 5B, 23/34 embryos). To confirm the non-cell-autonomous activity of dharma, we injected dharma mRN A with FITC-biotin-dextran directly into the yolk cell of embryos at the 1000-cell stage and examined the effect on gsc expression. We sel ected embryos in which the fluorescence had clearly distributed into the YSL at the sphere stage (Fig. 5C). These embryos displayed a lateral expansion of gsc expression (Fig. 5E). Histological anal ysis revealed that the expanded gsc was localized to the blastoderm overlying the YSL containing the FITCbiotin-dextran (Fig. 5F). Embryos allowed to devel op to later stages di splayed si milar phenotypes to those of embryos injected with the dharma RNA at the one-cell stage (Fig. 5D, Table 2). The yolk cell has been reported to possess mesoderm- and organizer-inducing activities in zebrafish (Mizuno et al. 1996). These data indicate that dharma expressed in the yolk cell enhanced its organizer-inducing activity, and that this induction occurred non-cell-autonomously.

\section{Discussion}

Zebrafish has become a very useful model for studying vertebrate devel opment, because various methods such as transplantation, cell-lineage tracing, and genetic analysis are available to analyze the embryos. In this study, we carried out an expression-cloning strategy in zebrafish that was previously used in Xenopus to isol ate genes involved in the DV axis formation. We successfully obtained a novel homeobox gene, dharma, which conferred the organizer-inducing activity in zebrafish. In addition, our results show that the expression-cloning strategy is a val uable technique in zebrafish and, in combination with genetic analysis, it will facilitate the isolation of genes involved in early embryogenesis in zebrafish.

dharma is one of the earliest zygotic genes that marks the dorsal side.

The expression of dharma was first detected in several bl astomeres at one side of the margin soon after the midblastula transition (MBT) (Fig. 4B,G), although at this stage no dorsal or ventral structure was apparent morphologically. Shortly after that, the expression domain narrowed and moved to the vegetal side (Fig. $4 \mathrm{C}, \mathrm{H}$ ). Its expression was restricted eventually to the dorsal side of 


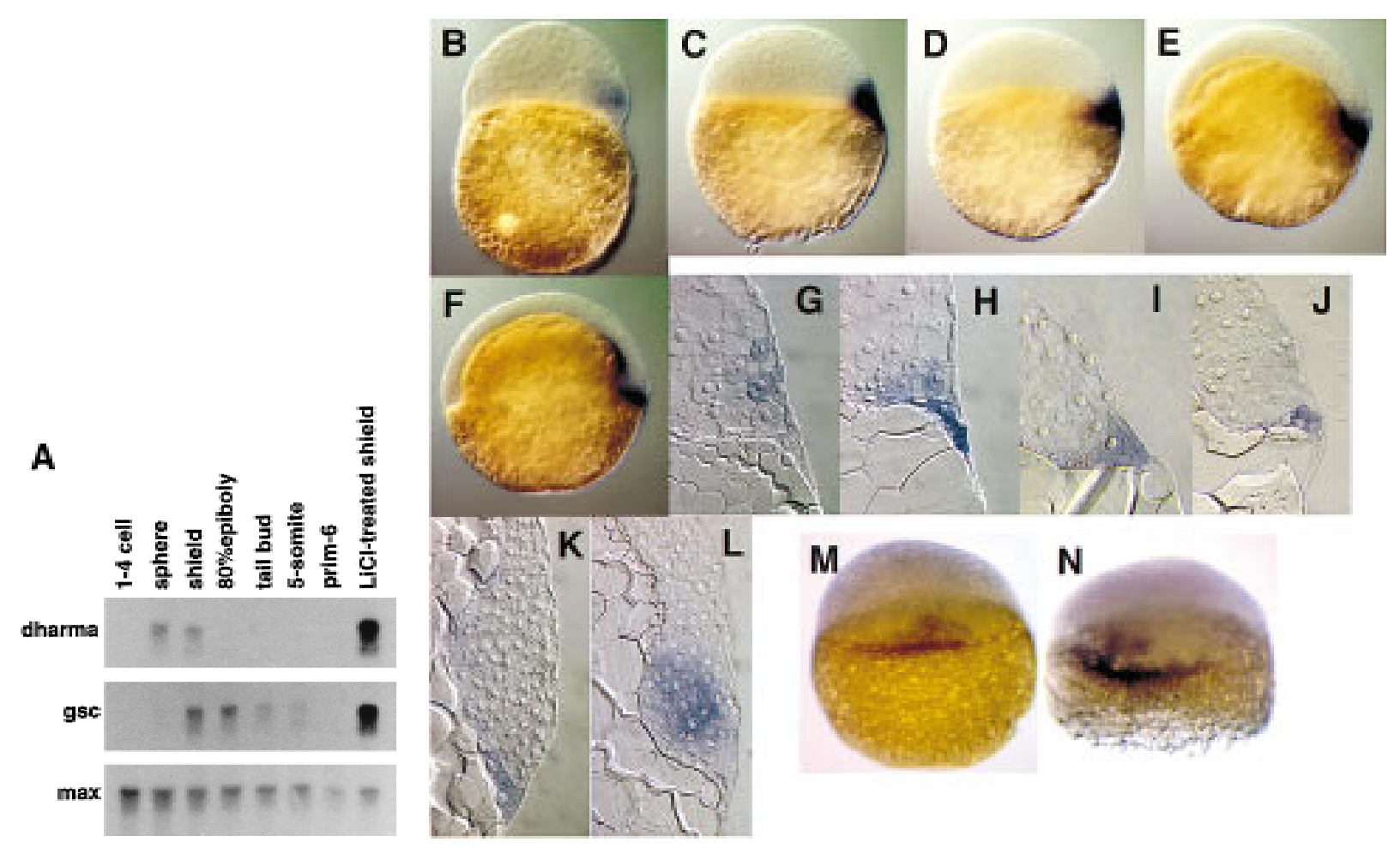

Figure 4. Expression of dharma transcripts during embryogenesis. (A) N orthern bl otting analysis (15 $\mu$ g of total RN As were loaded). max was used as a loading control. (B-K) Whole-mount in situ hybridization of dharma (B-F) and its sagittal section (G-K). (B,G) High stage, $(C, H)$ sphere stage, $(D, I)$ dome stage, $(E, J) 50 \%$ epiboly stage, $(F, K)$ shield stage. $(B-F)$ Lateral view. Right is dorsal. $(L)$ gsc expression at the shield stage. $(\mathrm{M}, \mathrm{N})$ dharma expression at the sphere stage. Dorsal view. (M) Control embryo; (N) LiCl-treated embryo.

the YSL, which is clearly located under the embryonic shield at the shield stage (Fig. 4F,K). Although no other markers indicate that dharma is expressed in the dorsal side in earlier stages, it is likely that dharma marks the prospective dorsal side and that DV axis is al ready determined at the time of MBT in zebrafish.

Studies of Xenopus embryos have reveal ed that asymmetric accumulation of $\beta$-catenin is an essential step in the DV axis determination. $\beta$-Catenin is maternally encoded and the $\beta$-catenin protein has been reported to accumulate in the future dorsal side during the first cleavage in Xenopus (Larabell et al. 1997). Although the mechanism of its asymmetric distribution is not yet clear, the Wnt signaling pathways have been suggested to be involved in this process (C adigan and $\mathrm{N}$ usse 1997; Moon et al. 1997b). Biochemical and genetic analyses of Wnt and Drosophila Wingless signaling revealed that glycogen synthetase kinase 3 (GSK3) regulates negatively the stability of the $\beta$-catenin protein, and that activation of the Wnt pathways represses the activity of GSK3, resulting in the stabilization of $\beta$-catenin and its nuclear accumulation. $\beta$-Catenin forms a complex with the transcription factors Lef 1 or T cf3, enters the nucl eus with them, and modi fies the activity of these DN A-binding proteins (Behrens et al. 1996; Molenaar et al 1996). $\mathrm{LiCl}$ treatment, which has been reported to inhibit the activity of GSK3 (Klein and M elton 1996), was shown to cause the ectopic accumulation of $\beta$-catenin, to induce expansion of the organizer, and to result in hyperdorsal- ized phenotypes in Xenopus embryos, as observed in embryos expressing a dominant-negative GSK3 (Larabell et al. 1997). In zebrafish, $\beta$-catenin was shown to accumulate in the nuclei of the YSL and dorsal marginal blastomeres in the blastula stage (Schneider et al. 1996). Zebrafish embryos treated with $\mathrm{LiCl}$ also exhibit hyperdorsalized phenotypes with expansion of the organizer (Stachel et al. 1993). Here we found dharma to be expressed in the dorsal YSL and its expression to be enhanced by $\mathrm{LiCl}$ treatment (Fig. $4 \mathrm{~A}, \mathrm{~N}$ ). These data suggest that the mechanism of the initial DV axis determination is conserved between Xenopus and zebrafish. dharma is likely to be regulated by $\beta$-catenin that has accumulated in the nuclei of the dorsal YSL. There are several consensus Tcf/Lef-binding sites in the dharma promoter region (Y. Yamanaka, M. Hibi, and T. Hirano, unpubl.). We detected dharma expression in the marginal cells at the high stage. It is not clear yet whether these cells belong to cells involuting in the shield stage or noninvoluting cells including envel oping layer (EVL) or noninvoluting endocytic marginal cells (NEM, prospective forerunner cells) (Cooper and D'Amico 1996). Recently EVL and NEM cells were shown to connect functionally with the YSL (D'Amico and Cooper 1997). dharma-expressing cells may be EVL or NEM cells, but further analysis will be required to clarify this issue. We do not exclude the possibility that dharma in the blastoderm is involved in a part of the organizer formation, by a cell-autonomous manner. 


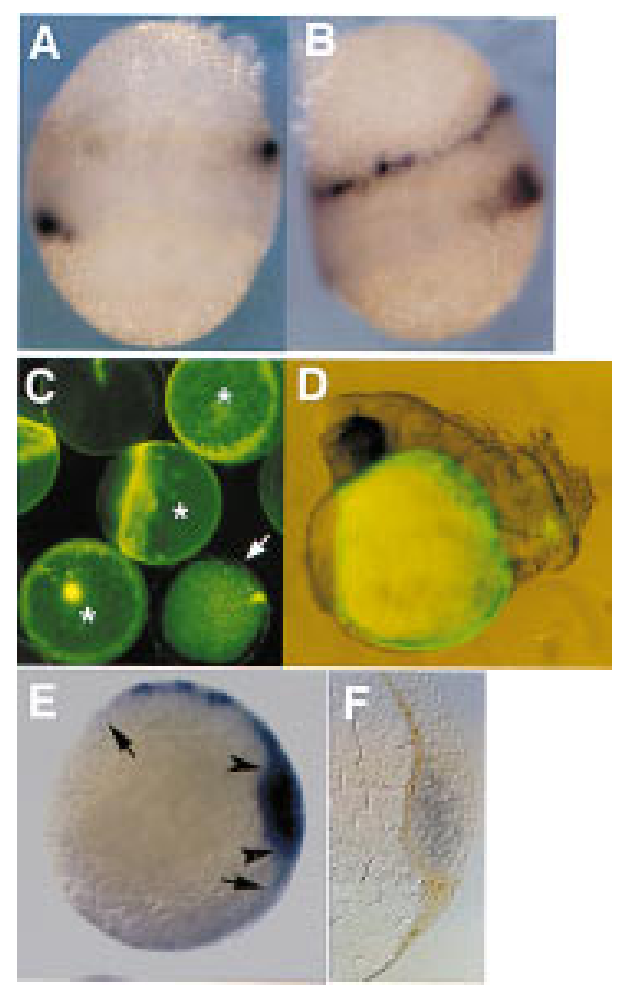

Figure 5. dharma induced the gsc expression in a non-cellautonomous manner. $(A, B)$ gsc expression in the yolk-transplanted embryo. U pper yolk cells are from donor embryos. Control yolk-transplanted embryo (A); dharma mRNA-injected yolk-transplanted embryo (B) at the shield stage. (C) Embryos in which the YSL was injected with dharma RNA and FITC-biotin-dextran at the 1000-cell stage. The embryos were observed by fluorescein microscopy at the sphere stage. Properly injected YSLs were fluorescent when examined using a fluorescein filter $(*)$, and the embryos bearing these YSLs were selected and subjected to further analysis (D-F). In certain injected embryos $(\rightarrow)$, fluorescein was observed in the blastoderm. (D) Embryo whose YSL was injected with dharma RNA and FITC-biotin-dextran at $24 \mathrm{pfh}$. N ote that fluorescence is restricted to the yolk cell. The embryo displays a hyperdorsal ized phenotype. (E,F) gsc expression in an embryo that overexpressed dharma mRNA in its yolk cell. (E) Animal pole view. (Arrowheads) Region of the endogenous gsc expression; (arrows) expanded gsc expression. (F) Sagittal section of YSL-injected embryo. gsc expression was analyzed in the embryo at the shield stage by in situ hybridization (blue). The localization of FITC-biotin-dextran was visualized by biotin-avidin peroxidase staining (brown).

\section{dharma defines a dorsalizing center}

Among the molecules identified as having dorsalizing activities, only siamois (Lemaire et al. 1995) and twin (Laurent et al. 1997), the Xenopus homeobox genes, are also candidates for involvement in the non-cell-autonomous induction of the organizer. Both siamois and twin are expressed soon after M BT. Their expression restores the complete dorsal axis in embryos lacking dorsal structures (ventral ized embryos). siamois is expressed more in vegetal cells than cells expressing Xbra, which is a panmesoderm marker (the ortholog of zebrafish ntl) at the blastula stage. Furthermore, siamois could induce a complete secondary axis when its RN A was injected into the ventral-vegetal blastomere, which does not normally contribute to the formation of the organizer tissue. This result suggests that siamois is able to induce the organizer in a non-cell-autonomous manner and that it may confer a dorsalizing center-like activity to cells that express it. However, siamois and twin are normally expressed in the dorsal marginal zone, which gives rise to the organizer. Twin regulates the expression of gsc by direct binding to its promoter (Laurent et al. 1997), suggesting siamois and twin may not be involved in the non-cell-autonomous induction of the organizer, and therefore they may be organizer genes involved in the cell-autonomous organizer formation.

Transplantation of the dorsal-vegetal blastomeres of a 32-cell-stage Xenopus embryo, either into a ventralized embryo or into the ventral side of a normal embryos, leads to axis induction (Gimlich and Gerhart 1984; Gimlich 1986). Lineage tracing reveal ed that the dorsal vegetal blastomeres do not differentiate to the organizer tissue (Gimlich 1986). This vegetal-dorsalizing region has been called the N ieuwkoop center. Transplantation experiments further revealed that the $\mathrm{Nieuwkoop}$ center loses the organizer-inducing activity in the late blastula (Boterenbrood and Nieuwkoop 1973; Jones and Woodland 1987), suggesting that the function of the Nieuwkoop center relies on maternal genes.

Zygotic genes were al so suggested to be implicated in the formation of a dorsalizing center that induces the organizer in a non-cell-autonomous manner. Animal caps overexpressing $\beta$-catenin could dorsal ize adjacent mesoderm without mesoderm induction (Wylie et al. 1996), indicating that $\beta$-catenin, not only induces the organizer-specific genes such as Xnr3 and siamois, but is involved also in the formation of a dorsalizing center. The relationship between the $\mathrm{N}$ ieuwkoop center and the dorsalizing center has not been clear yet. Here we present evidence that the dharma-expressing YSL acts as a zebrafish zygotic-dorsalizing center and that dharma is involved in its formation. First, embryos injected with dharma RN A displayed expanded gsc expression, which marks the organizer (Fig. 3A,B). Later the embryos contained expanded or multiple axial structure marked by ntl expression (Fig. 3D,E), indicating that the overexpression of dharma could induce the functional organizer ectopically. Furthermore, and most importantly, the experiments of yolk transplantation and RNA injection into the YSL showed that yolk cells overexpressing dharma RNA could induce the expanded expression of gSC in blastomeres (Fig. 5B,E), indicating that dharma can induce the organizer in a non-cell-autonomous manner. These results show that the dharma-expressing YSL is a dorsalizing center that does not give rise to the organizer itself, but induces it in a non-cell-autonomous manner. In this sense, the dharma-expressing YSL is likely equivalent to the $\mathrm{Nieuwkoop}$ center of Xenopus, although this issue remains to be clarified. Dharma is a transcription factor and inductive signals should be sol uble protein(s) or adhesion molecule(s), and dharma is 
Table 2. Injection of dharma mRNA into YSL

\begin{tabular}{lccccc}
\hline & & \multicolumn{2}{c}{24 pfh } \\
\cline { 3 - 5 } & $\begin{array}{c}\text { No. of } \\
\text { embryos }\end{array}$ & Snh-like & tail & abnormality & normal \\
\hline Control injection & 25 & 0 & 0 & 24 & 1 \\
dharma mRNA injection & 32 & 8 & 15 & 9 & 0 \\
\hline
\end{tabular}

probably involved in the gene expression of such inductive signals. Thus, dharma is the first zygotic gene to be implicated in the formation of a dorsalizing center in vertebrates and provides a basis for unerstanding its molecular nature.

Intriguingly, when dharma RNA was injected into one-cell-stage embryos, the entire blastomeres expressed dharma, but ectopic gsc expression was observed only in the marginal zone of blastomeres, as observed in embryos with the dharma-overexpressing YSL. This indicates that dharma expression alone is not sufficient to form the dorsalizing center and that additional factors restricted to the YSL are needed to complete the organizer-inducing activity.

Our data show that the dharma-expressing YSL is the dorsalizing center in zebrafish and it is separated completely from the prospective organizer tissue, which is located in the blastoderm (Driever 1995; Westerfield 1995). In Xenopus embryos, the yolky cells that are equivalent to the YSL are not distinct morphologically from the prospective organizer tissue. This structure may make it difficult to distinguish between a non-cellautonomous induction and a cell-autonomous establishment of the organizer in Xenopus embryos. Alternatively, it is possible that the organizer devel ops in a cellautonomous manner in amphibia. Although it is still possible that cell-autonomous mechanism(s) are involved in the formation of the organizer in cooperation with the inductive signals, our present data provide the first molecular evidence for the existence of an inductive signal for the formation of the organizer in zebrafish.

\section{Materials and methods}

Fish maintenance

Zebrafish (Danio rerio) were purchased from a pet shop in Osaka. Adult fish were maintained at $28.5^{\circ} \mathrm{C}$ and in a $14-\mathrm{hr}$ light/10-hr dark cycle. Embryos from the zebrafish spawn were collected $15 \mathrm{~min}$ after the light was turned on. Embryos were washed and cultured at $28.5^{\circ} \mathrm{C}$ in embryonic medium. The embryonic stages were determined by the postfertilization hour and by microscopic observation, referring to descriptions in The zebrafish book (Westerfield 1995).

Expression cloning of a cDNA with activity affecting body axis formation

LiCl-treated embryos were obtained by treating embryos with $0.3 \mathrm{M} \mathrm{LiCl}$ in embryonic medium for $10 \mathrm{~min}$ at the 128- to 512-cell stage. When embryos reached the shiel d stage, the total RNA was extracted by Trizol reagent (GIBCO-BRL), and $\operatorname{poly}(A)^{+}$RNA was obtained using the Fast Track Kit (Invitro- gen). A plasmid cDN A library was constructed using the SuperScript Plasmid system, and the cDN As were inserted into the pCM V-Sport expression vector (GIBCO-BRL). The Escherichia coli transformants were divided into pools containing $\sim 200$ clones each. Plasmid DNA was isolated from each pool, and 5 '-capped RN As were synthesized in vitro using SP6 RN A polymerase.

Synthetic RN A from each pool was injected into blastomeres (1-2 ng RNA per blastomere), in one- to eight-cell-stage embryos (30 embryos/pool). The effects of RNA injection were evaluated at 24 pfh by microscopic observation, and their abnormalities were scored into categories such as snake-tail, radialization, and secondary-axis. One strongly active pool was obtained out of 200 pools $(40,000$ clones), and from this pool, one positive clone was isolated by sib selection. The nucleotide sequence data reported in this paper will appear in the DDBJ, $\mathrm{EMBL}$, and GenBank nucleotide sequence databases under accession number AB010103.

RNA and dye injection

Synthetic RN As were dissolved in $0.2 \mathrm{M} \mathrm{KCl}$ with $0.2 \%$ phenol red as a dye, and injected into one-cell-stage embryos using a PV830 Pneumatic PicoPump (WPI). At 2 pfh, unfertilized eggs were removed. Injection into yolk cells was performed at the 1000-cell stage. One-hundred picograms of dharma mRN A was injected with FITC-biotin dextran (10 kM W, M olecular Probe).

\section{Whole-mount in situ hybridization and probes}

Whole-mount in situ hybridization with RNA probes was performed as described previously (Jowett and Lettice 1994), except that BM Purple AP substrate (Boehringer M annheim) was used for the alkaline phosphatase substrate. The entire dharma mRN A and a 465-bp fragment (1-465, with the homeobox removed) were used as probes for N orthern blotting and wholemount in situ hybridization, respectively. gsc and ntl probes were obtained by RT-PCR using the primer pairs described previously (Sagerstrom et al. 1996).

\section{Secondary axis formation in the Xenopus embryo}

RNA injection was performed at the eight-cell stage. One hundred picograms of dharma mRN A was injected into the ventralvegetal cell (approximately corresponding to the D4 region at the 32-cell stage) with $40 \mathrm{pg} \beta$-galactosidase mRNA. Injected embryos were harvested at the tadpol estage. Three independent experiments were performed and gave reproducible results.

Yolk-cell transplantation

Donor embryos were labeled by biotin-dextran injection until the eight-cell stage. Both donor and host embryos were dechorionated with trypsin in one-third Ringer solution before transplantation. At the sphere stage, donor embryos were incubated in $\mathrm{Ca}^{2+}$-free one-third Ringer solution to remove the blastoderm 
cells from their yolk cell. The donor yolk cell was transplanted onto the animal-pole region of a host embryo at the same developmental stage, in normal Ringer solution. The chimeric embryos were grown to the shield stage in one-third Ringer solution, then fixed by $4 \%$ paraformaldehyde in PBS. After whole-mount in situ hybridization, the donor yolk cell was visualized by biotin-avidin peroxidase staining (data not shown; ABC kit; Vectastain).

\section{Acknowledgments}

We thank R. Moon, K. Helde, and D.J. Grunwald for various reagents and helpful suggestions; $M$. Shinya for her advice; $Y$. Kuga for her technical assistance in histological sectioning; and the members of our laboratory zebrafish team for discussions. We also thank R. Masuda and T. Kimura for secretarial assistance. This work was supported by grants and a Grant-in-Aid for Center of Excellence (COE) Research from the Ministry of Education, Science, Sports, and Culture in Japan.

The publication costs of this article were defrayed in part by payment of page charges. This article must therefore be hereby marked "advertisement" in accordance with 18 USC section 1734 solely to indicate this fact.

\section{References}

Bauer, D.V., S. Huang, and S.A. M oody. 1994. The cleavage stage origin of Spemann's Organizer: Analysis of the movements of blastomere clones before and during gastrulation in Xenopus. Development 120: 1179-1189.

Behrens, J., J.P. von Kries, M. Kuhl, L. Bruhn, D. Wedlich, R. Grosschedl, and W. Birchmeier. 1996. Functional interaction of $\beta$-catenin with the transcription factor LEF-1. Nature 382: 638-642.

Boterenbrood, E.C. and P.D. Nieuwkoop. 1973. The formation of the mesoderm in Urodelan amphibians: V. Its regional induction by the endoderm. Wilhel m Roux's Arch. 173: 319332.

Cadigan, K.M. and R. N usse. 1997. Wnt signaling: A common theme in animal development. Genes \& Dev. 11: 3286-3305.

Cho, K.W.Y., B. Blumberg, H. Steinbeisser, and E.M. De Robertis. 1991. M olecular nature of Spemann's organizer: The role of the Xenopus homeobox gene goosecoid. Cell 67: 11111120.

Cooper M.S. and L.A. D'Amico. 1996. A cluster of noninvoluting endocytic cells at the margin of the zebrafish blastoderm marks the site of embryonic shield formation. Dev. Biol. 180: 184-198.

D'Amico, L.A. and M.S. Cooper. 1997. Spatially distinct domains of cell behavior in the zebrafish organizer region. Biochem. Cell Biol. 75: 563-577.

Darras, S., Y. Marikawa, R.P. Elinson, and P. Lemaire. 1997. A nimal and vegetal pole cells of early Xenopus embryos re spond differently to maternal dorsal determinants: Implications for the patterning of the organiser. Development 124: $4275-4286$.

Driever, W. 1995. Axis formation in zebrafish. Curr. Opin. Genet. Dev. 5: 610-618.

Gallagher, B.C., A.M. Hainski, and S.A. Moody. 1991. Autonomous differentiation of dorsal axial structures from an animal cap cleavage stage bl astomere in Xenopus. Devel opment 112: 1103-1114.

Gimlich, R.L. 1986. Acquisition of developmental autonomy in the equatorial region of the Xenopus embryo. Dev. Biol. 115: $340-352$.
Gimlich, R.L. and J.C. Gerhart. 1984. Early cellular interactions promote embryonic axis formation in Xenopus laevis. Dev. Biol. 104: 117-130.

Hammerschmidt, M., G.N. Serbedzija, and A.P. McMahon. 1996. Genetic analysis of dorsoventral pattern formation in the zebrafish: Requirement of a BM P-like ventralizing activity and its dorsal repressor. Genes \& Dev. 10: 2452-2461.

Heasman, J. 1997. Patterning the Xenopus blastula. Development 124: 4179-4191.

Jones C.M. and H.R. Woodland. 1987. The development of animal cap cells in Xenopus: A measure of the start of animal cap competence to form mesoderm. Devel opment 101: 557564.

Jowett, T. and L. Lettice. 1994. Whole-mount in situ hybridizations on zebrafish embryos using a mixture of digoxigeninand fluorescein-labelled probes. Trends Genet. 10: 73-74.

Kageura, H. 1990. Spatial distribution of the capacity to initiate a secondary embryo in the 32-cell embryo of Xenopus Iaevis. Dev. Biol. 142: 432-438.

Klein, P.S. and D.A. M elton. 1996. A molecular mechanism for the action of lithium during early development. Proc. Natl. Acad. Sci. 93: 8455-8459.

Larabell, C.A., M. Torres, B.A. Rowning, C. Yost, J.R. Miller, M. Wu, D. Kimelman, and R.T. Moon. 1997. Establishment of the dorso-ventral axis in Xenopus embryos is presaged by early asymmetries in beta-catenin that are modulated by the Wnt signaling pathway. J. Cell Biol. 136: 1123-1136.

Laurent, M.N., I.L. Blitz, C. Hashimoto, U. Rothbacher, and K.W.-Y. Cho. 1997. The Xenopus homeobox gene Twin mediates Wnt induction of Goosecoid in establishment of Spemann's organizer. Development 124: 4905-4916.

Lemaire, P. and J.B. Gurdon. 1994. A role for cytoplasmic determinants in mesoderm patterning: Cell-autonomous activation of the goosecoid and Xwnt-8 genes al ong the dorsoventral axis of early Xenopus embryos. Devel opment 120: 11911199.

Lemaire, P. and L. Kodjabachian. 1996. The vertebrate organizer: Structure and molecules. Trends Genet. 12: 525-531.

Lemaire, P., N. Garrett, and J.B. Gurdon. 1995. Expression cloning of Siamois, a Xenopus homeobox gene expressed in dorsal-vegetal cells of blastulae and able to induce a complete secondary axis. Cell 81: 85-94.

Mizuno, T., E. Yamaha, M. Wakahara, A. Kuroiwa, and H. Takeda. 1996. Mesoderm induction in zebrafish. Nature 383: 131-132.

Moon, R.T., J.D. Brown, J.A. Yang Snyder, and J.R. Miller. 1997a. Structurally related receptors and antagonists compete for secreted Wnt ligands. Cell 88: 725-728.

Moon, R.T., J.D. Brown, and M. Torres. 1997b. Wnts modulate cell fate and behavior during vertebrate development. Trends Genet. 13: 157-162.

M olenaar M., M. van de Wetering, M. Oosterwegel, J. PetersonM aduro, S. Godsave, V. Korinek, J. Roose, O. Destree, and H. Clevers. 1996. XTcf-3 transcription factor mediates $\beta$ catenin-induced axis formation in Xenopus embryos. Cell 86: 391-399.

Mullins, M.C., M. Hammerschmidt, D.A. Kane, J. Odenthal, M. Brand, F.J.M. van Eeden, M. Furutani-Seiki, M. Granato, P. Haffter, C.-P. Heisenberg, Y.-J. Jiang, R.N. Kelsh, and C. N usslein-Volhard. 1995. Genes establishing dorsoventral pattern formation in the zebrafish embryo: The ventral specifying genes. Devel opment 123: 81-93.

Nieuwkoop, P.D. 1969. The formation of the mesoderm in urodelean amphibians. I. Induction by the endoderm. Wilhelm Roux's Arch. EntwMech. Org. 162: 341-373.

Sagerstrom, C.G., Y. Grinbalt, and H. Sive. 1996. Anteroposte- 
rior patterning in the zebrafish, Danio rerio: An explant assay reveals inductive and suppressive cell interactions. Development 122: 1873-1883.

Sakai, M. 1996. The vegetal determinants required for the Spemann organizer move equatorially during the first cell cycle. Development 122: 2207-2214.

Sasai, Y., and E.M. De Robertis. 1997. Ectodermal patterning in vertebrate embryos. Dev. Biol. 182: 5-20.

Schneider, S., H. Steinbeisser, R.M. Warga, and P. Hausen. 1996. Beta-catenin translocation into nuclei demarcates the dorsalizing centers in frog and fish embryos. Mech. Dev. 57: 191-198.

Schulte-M erker, S., R.K. Ho, B.G. Herrmann, and C. N usslein Volhard. 1992. The protein product of the zebrafish homologue of the mouse T gene is expressed in nuclei of the germ ring and the notochord of the early embryo. Development 116: 1021-1032.

Schulte-M erker, S., M. Hammerschmidt, D. Beuchle, K.W. Cho, E.M. De Robertis, and C. N usslein Vol hard. 1994. Expression of zebrafish goosecoid and no tail gene products in wild-type and mutant no tail embryos. Development 120: 843-852.

Slack, J.M.W. 1994. Inducing factors in Xenopus early embryos. Curr. Biol. 4: 116-126.

Smith, W.C. and R.M. Harland. 1991. Injected Xwnt-8 RN A acts early in Xenopus embryos to promote formation of a vegetal dorsalizing center. Cell 67: 753-765.

Smith, W.C. and R.M. Harland. 1992. Expression cloning of noggin, a new dorsalizing factor local ized to the Spemann organizer in Xenopus embryos. Cell 70: 829-840.

Stachel, S.E., D.J. Grunwald, and P.Z. Myers. 1993. Lithium perturbation and goosecoid expression identify a dorsal specification pathway in the pregastrula zebrafish. Development 117: 1261-1274.

Taira, M., M. Jamrich, P.J. Good, and I.B. Dawid. 1992. The LIM domain-containing homeo box gene Xlim-1 is expressed specifically in the organizer region of Xenopus gastrula embryos. Genes \& Dev. 6: 356-366.

Takasaki, H. 1987. Tates and roles of the presumptive organizer region in the 32-cell embryo in normal development of Xenopus laevis. Dev. Growth Differ. 29: 141-152.

Westerfield, M. 1995. The zebrafish book, 3rd ed. University of Oregon Press, Eugene, OR.

Wylie, C., M. Kofron, C. Payne, R. Anderson, M. Hosobuchi, E. Joseph, and J. Heasman. 1996. Maternal $\beta$-catenin establishes a dorsal signal in early Xenopus embryos. Development 122: 2987-2996. 


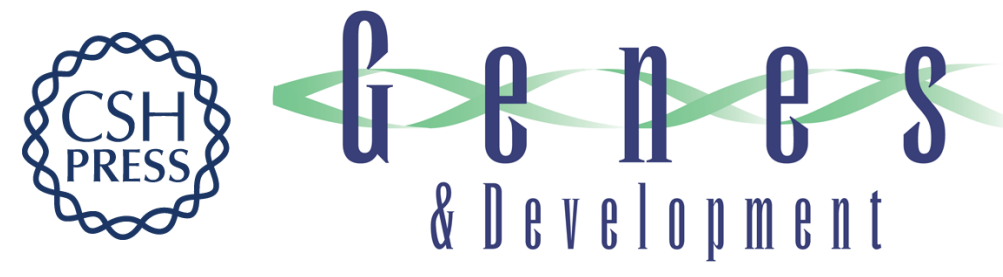

\section{A novel homeobox gene, dharma, can induce the organizer in a non-cell-autonomous manner}

Yojiro Yamanaka, Toshiro Mizuno, Yoshiki Sasai, et al.

Genes Dev. 1998, 12:

Access the most recent version at doi:10.1101/gad.12.15.2345

References

This article cites 41 articles, 19 of which can be accessed free at: http://genesdev.cshlp.org/content/12/15/2345.full.html\#ref-list-1

License

Email Alerting

Receive free email alerts when new articles cite this article - sign up in the box at the top Service right corner of the article or click here.

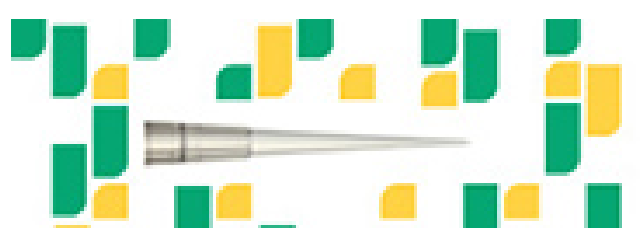

Focused on your science. 